\title{
Pengaturan, Penanganan dan Pertanggungjawaban Hukum bagi Pelaku Tindak Pidana Pembayaran Cek Giro Kosong
}

\section{Arrangement, Handling and Legal Liability for Perpetrators of Criminal Acts of Payment of Blank Checks}

\author{
Mahzaniar* \\ Fakultas Hukum, Universitas Muslim Nusantara
}

\begin{abstract}
Abstrak
Pelaksanaan pembayaran melalui cek giro kosong merupakan salah satu modus operandi kejahatan modern dewasa ini. Pembayaran melalui cek kosong dapat diklasifikasikan dan dimasukkan ke dalam kejahatan penipuan. Pengaturan hukum terhadap tindak pidana pembayaran melalui cek giro kosong diatur dalam Pasal 378 KUH Pidana. Artinya tindak pidana pembayaran melalui cek giro kosong tersebut dimasukkan ke dalam klasifikasi tindak pidana penipuan sebagaimana diatur dalam Pasal 378 KUH Pidana. Pihak yang terlibat dalam penanganan tindak pidana pembayaran melalui cek giro kosong adalah kepolisian. Karena Fungsi kepolisian adalah salah satu fungsi pemerintahan negara di bidang pemeliharaan keamanan dan ketertiban masyarakat, penegakan hukum, perlindungan, pengayoman, dan pelayanan kepada masyarakat. Pertanggungjawaban hukum bagi pelaku tindak pidana pembayaran melalui cek giro kosong tersebut dipidana atas perbuatannya tersebut. Apabila perbuatan pengancaman tersebut dilakukan secara sengaja, selanjutnya dilakukan secara sadar oleh seseorang yang waras serta diketahui perbuatan penipuan tersebut ada diatur di dalam perundang-undangan yaitu Pasal 378 KUHP, maka pada kapasitas ini pelaku penipuan dapat dimintakan pertanggungjawaban hukumnya. Kata Kunci: Tindak Pidana, Penipuan, Pembayaran, Cek Kosong
\end{abstract}

\begin{abstract}
Implementation of payment through blank checks is one of the modern modus operandi of crime today. Payments through blank checks can be classified and put into crime fraud. The legal arrangements for the criminal acts of payment through blank checks are stipulated in Article 378 of the Criminal Code. This means that the criminal act of payment through blank check is entered into the classification of fraud criminal acts as stipulated in Article 378 of the Criminal Code. The party involved in handling the crime of payment through blank check is the police. Because the function of the police is one of the functions of state government in the field of maintaining security and public order, law enforcement, protection, penganyoman, and service to the community. The legal liability for the perpetrator of a criminal act of payment through the blank check is punished for the act. If the act of intimidation is done intentionally, then done consciously by a sane person and known the act of fraud there is regulated in the legislation that is Article 378 of the Criminal Code, so in this capacity the perpetrators of fraud can be held accountable law.
\end{abstract}

Keywords: Crime, Fraud, Payment, Empty Check

How to Cite: Mahzaniar, (2017). Pengaturan, Penanganan dan Pertanggungjawaban Hukum bagi Pelaku Tindak Pidana Pembayaran Cek Giro Kosong. JPPUMA: Jurnal Ilmu Pemerintahan dan Sosial Politik UMA, 5 (2): 94-107

*Corresponding author:

p-ISSN: 25491660

E-mail: mahzaniar@gmail.com

e-ISSN: 2550-1305 


\section{PENDAHULUAN}

Perkembangan dunia usaha diikuti dengan perkembangan perbankan sebagai lembaga yang dapat menghimpun dan menyalurkan dana masyarakat. Semakin pesatnya perkembangan perdagangan akan mempengaruhi perkembangan perbankan karena masyarakat semakin berpikir praktis dan efisien untuk membantu kelancaran lalu lintas pembayaran. Uang sebagai alat pembayaran juga terus mengalami perkembangan, dahulu tukar menukar barang dilakukan dengan cara barter. Perkembanganpun terjadi, muncullah uang yang berfungsi sebagai alat pembayaran sehingga proses tukar menukar barang menjadi semakin efektif. Inovasi dalam pembayaran juga terus dikembangkan oleh sistem perbankan untuk mengantisipasi besarnya resiko dalam pembayaran tunai dalam jumlah besar. Inovasi ini dikenal dengan pembayaran non tunai dalam bentuk surat berharga karena mempunyai kelebihan efisien, cepat dan aman.

Perkembangan dalam bidang usaha yang semakin pesat menyebabkan orangorang menginginkan segala sesuatu bersifat praktis dan aman dalam lintas pembayaran. Kerjasama antara pengusaha dengan bank terjakin, untuk saling membantu dan menolong demi kemajuan masing-masing serta demi kelancaran lalu lintas pembayaran. Sistem pembayaran dalam dunia bisnis mulai berubah dari pembayaran tunai ke pembayaran giral rekening giro bank, sehingga bisa dilakukan dengan cepat dan efisien.

Salah satu bentuk surat berharga tersebut adalah bilyet giro. Bilyet giro adalah Surat perintah nasabah kepada bank penyimpan dana untuk memindah bukukan sejumlah dana dari rekening yang bersangkutan kepada pihak penerima yang disebut namanya pada bank yang sama atau berlainan. Pembayaran dana bilyet giro tidak dapat dilakukan dengan uang tunai yang berarti bahwa sistem pembayaran dengan booking transfer dan tidak dapat dipindah tangankan dengan endosemen (pembubuhan cap) (Kadir, 2003: 224).

Bilyet Giro yang sudah dirasa aman tidak seperti cek dan wesel yang dapat diuangkan oleh orang yang tidak bertanggungjawab, tetapi masih bisa dimanfaatkan oleh orang yang tidak bertanggung jawab yang dilakukan dengan bilyet giro kosong. Berdasarkan Surat Keputusan Direksi Bank Indonesia No 28/32/Dir tanggal 4 juli 1995 penerbit disini memiliki wewenang untuk membatalkan. Pembatalan karena dana penerbit tidak cukup. Permasalahan disini muncul ketika dana tidak cukup atau tidak ada tetapi bilyet giro tersebut sudah beredar atau dipegang oleh pemegang dan merugikan pemegang bilyet giro.

Bilyet giro ini merupakan surat berharga yang tidak diatur dalam Kitab Undang-Undang Hukum Dagang (KUHD), yang tumbuh dan berkembang dalam praktik perbankan karena kebutuhan dalam lalu lintas pembayaran secara giral (Kadir, 2003: 224). Untuk mengatasi hal inilah maka Direksi Bank Indonesia mengeluarkan Surat Keputusan No. 28/32/Kep/Dir Tahun 1995 menggantikan Surat Edaran Bank Indonesia No. 4/670/UPPB/PbB Tahin 1972 tentang Bilyet Giro

Secara yuridis formal, bilyet giro ini belum ada Undang-undang yang mengatur tentang bilyet giro, hanya pedoman atau pengaturan yang diterbitkan oleh Bank Indonesia sebagai Bank Sentral yaitu SEBI No. 28/32/Dir tanggal 4 Juli 1995 yang mulai berlaku tanggal 1 November 1995. Dalam SEBI ini ditegaskan mengenai Bilyet Giro secara khusus. Bilyet giro tidak lain dari surat perintah tak bersyarat dari nasabah yang telah dibakukan bentuknya kepada bank penyimpan dana untuk memindahkan sejumlah dana dari rekening giro yang bersangkutan kepada pihak penerima yang disebut namanya kepada bank yang sama atau pada bank lainnya (Suryohadibroto dan Djoko, 2009: 21)

Para pihak yang terlibat transaksi dalam menggunakan bilyet giro adalah 
bank, nasabah atau penerbit dan pihak pemegang atau penerima bilyet giro yang masing-masing pihak mempunyai hak dan kewajiban. Akan tetapi sangat disayangkan dalam praktek sehari-hari terutama dalam dunia usaha masih dapat dimanfaatkan oleh orang-orang yang tidak bertanggung jawab, jadi penggunaan bilyet giro ini pembayaran sering terjadi dengan Bilyet Giro kosong.

Pelaksanaan pembayaran melalui cek giro kosong adalah merupakan salah satu modus operandi kejahatan modern dewasa ini. Sebagai suatu kejahatan maka pembayaran melalui cek kosong dapat diklasifikasikan dan dimasukkan ke dalam kejahatan penipuan. Tindak pidana penipuan (bedrog) dimuat dalam Bab XXV Buku II KUHP dari Pasal 378 sampai dengan Pasal 395. Titel asli bab ini adalah bedrog yang oleh banyak ahli diterjemahkan sebagai penipuan, atau ada juga menerjemahkannya sebagai perbuatan curang (Chazawi, 2003: 115).

Perbuatan menipu itu adalah suatu perbuatan yang dapat memperdaya seorang yang berpikiran normal. Contohnya mengadakan jual beli barang yang berkualitas tinggi, tetapi penjual menyerahkan barang tersebut kepada pembeli dengan kualitas rendah sehingga pembeli barang tersebut ditipu oleh si penjual barang tadi. (Arifin, 2012: 105)

Pelaku penipuan biasanya mempunyai alasan atau rasionalisasi yang membuat mereka merasa perilaku yang illegal tersebut sebagai sesuatu yang wajar. Para pelaku membuat rasionalisasi bahwa mereka sebenarnya tidak benar-benar berlaku tidak jujur atau bahwa alasan mereka melakukan penipuan lebih penting daripada kejujuran dan integritas. Seseorang didakwa telah melakukan penipuan dengan cara pembayaran melalui cek kosong sehingga oleh Jaksa Penuntut Umum terdakwa didakwa dengan dakwaan melanggar Pasal 378 KUHPidana sebagai dakwaan primair dan dakwaan subsidair terdakwa telah melanggar Pasal 372 KUHP.

\section{PEMBAHASAN}

Cek giro adalah merupakan salah satu surat berharga. Istilah surat berharga merupakan terjemahan dari bahasa Belanda waarde papieren. Waarde berarti nilai dan dalam KUHD, waarde diartikan berharga dan papieren berarti kertas, sehingga waarde papieren berarti kertas berharga. Disamping istilah waarde papieren di atas, surat berharga saat ini sering juga disebut negotiable instruments, negotiable papers, transferable papers, dan commercial papers. Sedangkan surat yang berharga atau surat yang mempunyai nilai dikenal dengan sebutan papieren van waarde atau juga disebut letter of value.

Surat berharga atau commercial paper (negotiable instruments) merupakan alat bayar dalam transaksi perdagangan modern saat ini. Surat berharga ini digunakan sebagai pengganti uang yang selama ini telah digunakan sebagai alat tukar dalam perdagangan khususnya oleh kalangan pebisnis atau para pengusaha. Hal ini disebabkan karena menggunakan surat berharga dianggap lebih aman, praktis, dan merupakan suatu prestise tersendiri (lebih bonafit), sedang menjadi mode atau trend, surat berharga sudah menjadi komoditi dalam kegiatan bisnis atau objek perjanjian, sehingga lebih menguntungkan dan lebih bervariasi.

Pengertian secara autentik tentang surat berharga ini tidak ditemukan dalam KUHD (Kitab Undang-undang Hukum Dagang), namun terdapat beberapa pendapat para sarjana yang berkaitan dengan surat berharga tersebut. Surat berharga atau surat yang berharga adalah akta-akta atau alat-alat bukti yang menurut kehendak dari penerbitnya atau ketentuan undang-undang yang diperuntukkan semata-mata sebagai upaya bukti diri (legitimasi), akta-akta tersebut diperlukan untuk menagih.

Jadi, surat berharga dapat dijadikan sebagai alat bukti atas suatu tuntutan terhadap penandatanganan surat tersebut, tuntutan itu dapat dipenuhi dengan membawa dan menyerahkan alat bukti yakni surat berharga yang dimaksud. 
Secara yuridis surat berharga termasuk cek giro mempunyai fungsi sebagai berikut: a) Sebagai alat pembayaran (alat tukar); b) Sebagai alat pemindahan hak tagih (karena dapat diperjual belikan; c) Sebagai surat legitimasi (surat bukti hak tagih).

Tindakan-tindakan penyalahgunaan cek giro ini seperti penerbitan cek giro kosong yang digolongkan sebagai perbuatan penipuan maka keadaan tersebut ditampung dalam KUH Pidana khususnya Pasal 372 dan Pasal 378 KUH Pidana.

Pasal 372: Barang siapa dengan sengaja dan melawan hukum memiliki barang sesuatu yang seluruhnya atau sebagian adalah kepunyaan orang lain, tetapi yang ada dalam kekuasaannya bukan karena kejahatan diancam karena penggelapan, dengan pidana penjara paling lama empat tahun atau pidana denda paling banyak sembilan ratus rupiah.

Pasal 378: Barang siapa dengan maksud untuk menguntungkan diri sendiri atau orang lain secara melawan hukum, dengan memakai nama palsu atau martabat palsu, dengan tipu muslihat, ataupun rangkaian kebohongan, menggerakkan orang lain untuk menyerahkan barang sesuatu kepadanya, atau supaya memberi hutang rnaupun menghapuskan piutang diancam karena penipuan dengan pidana penjara paling lama empat tahun.

Adapun pihak yang terlibat dalam penanganan tindak pidana pembayaran melalui cek kosong adalah pihak kepolisian. Hakekat fungsi kepolisian dalam suatu negara yang berdasar hukum seperti Indonesia maka Polri adalah aparatur penegak hukum sesuai Pasal 2 UU Nomor 2 tahun 2002 tentang Kepolisian Negara Republik Indonesia, yang berbunyi: "Fungsi kepolisian adalah salah satu fungsi pemerinatahan negara di bidang pemeliharaan keamanan dan ketertiban masyarakat, penegakan hukum, perlindungan, penganyoman, dan pelayanan kepada masyarakat", maka terlihat bahwa Polri mempunyai 3 (tiga) fungsi utama yaitu, preemtif, preventif dan represif.
Yang dimaksud pre-emtif adalah mencari dan menemukan akar permasalahan yang ada di masyarakat yang bersifat lintas sektoral (etnis, sosial, budaya, politik), preventif adalah tindakan pencegahan yang berorientasi kepada hasil akhir berupa kegiatan deteksi dini (early warning) sebagai landasan pengambilan kebijakan langkah antisipasi, sedangkan represif adalah suatu bentuk kegiatan penegakan hukum. Dalam hal fungsi represif penegakan hukum yang dilaksanakan oleh aparat Polri terhadap pelanggaran yang dilakukan oleh masyarakat dengan cara melakukan penipuan berupa pembayaran dengan memakai cek giro kosong.

Polri, dalam mengemban fungsi penegakan hukum untuk melindungi masyarakat dari penipuan berupa pembayaran dengan memakai cek giro kosong harus menjaga jangan sampai jalannya roda ekonomi tersebut terganggu atau terhenti dengan adanya tindak kejahatan yang dilakukan oleh sebagian masyarakat. Ketidakberdayaan masyarakat dalam menghadapi tindak pidana penipuan berupa pembayaran dengan memakai cek giro kosong ini jelas merugikan kepentingan masyarakat. Polri sebagai pengemban fungsi pelindung, pengayom dan pelayan masyarakat serta penegak hukum. Tugas kepolisian terhadap masyarakat/institusi yang melanggar hukum ialah melakukan penegakan hukum itu sendiri. Penegakan hukum oleh Polri dilakukan oleh Satuan Fungsi Reserse yang ada pada organisasi Polri. Pelanggaran hukum tersebut merupakan awal perputaran dari suatu proses peradilan pidana.

Proses peradilan pidana ini diatur dalam suatu sistem yang disebut sistem Peradilan Pidana (Criminal Justice Systemi) (Sunaryo, 2004: 257-261). Dalam sistem peradilan pidana ini Polri dalam hal ini fungsi reserse diberi wewenang untuk melakukan penyidikan dengan berdasar pada landasan hukum yang tercantum pada: a) Undang-Undang No. 2 Tahun 2002 tentang Kepolisian Negara Republik 
Indonesia (Pasal 14 ayat (1) huruf g dan Pasal 16), b) Undang-Undang No. 8 Tahun 1981 tentang Hukum Acara Pidana/KUHP (Pasal 7).

Dasar hukum tersebut di atas memberikan wewenang kepada Polri untuk melakukan penyidikan yang pelaksanaannya didelegasikan kepada Penyidik Polri (Satuan Reserse Kriminal). Peranan Reserse dalam sistem peradilan pidana berada pada bagian terdepan dan merupakan tahap awal mekanisme proses peradilan pidana yaitu: pemeriksaan pendahuluan. Tugas-tugas penyidikan itu berhubungan dengan penangkapan, penahanan, penggeledahan, penyitaan, pemeriksaan surat, pemeriksaan saksi/tersangka, bantuan seorang ahli (Dirdjosisworo, 1998: 54) Pemeriksaan pendahuluan dilakukan dalam arti bahwa suatu penyidikan dilakukan terhadap seseorang yang diduga melakukan suatu tindak pidana (Loqman, 1987: 25).

Hukum acara pidana (Hamzah, 1983: 19) yang menjadi kerangka kewenangan Polri untuk menyidik pelaku tindak pidana konsumen pada dasarnya dapat dilaksanakan meskipun baru ada persangkaan adanya orang yang melanggar atau memenuhi aturan hukum pidana. Ini berarti hukum acara pidana bukan saja menentukan secara resmi adanya pelanggaran terhadap hukum pidana, tetapi juga mengadakan tindakan meskipun baru ada persangkaan tindak pidana. (Sabuan, dkk, 1990: 64)

Penyelidikan adalah rangkaian proses penegakan hukum pidana yang dimulai dari prose penyidikan oleh Polri sebagai bagian dari kebijakan aplikatif hukum pidana (politik kriminal). Salah satu sarana dari politik kriminal adalah sarana penal atau penegakan hukum pidana yang tercakup dalam sistem peradilan pidana. Sistem peradilan pidana merupakan suatu jaringan (network) peradilan yang menggunakan hukum pidana sebagai sarana utamanya, baik hukum pidana materiil, hukum pidana formil maupun pelaksanaan pidana.
Namun demikian lembaga ini harus dilihat dalam kerangka atau konteks sosial (Muladi, 1995: 4). Sifat yang terlalu formal apabila dilandasi hanya untuk kepentingan kepastian hukum saja akan membawa kearah ketidakadilan. Dengan demikian demi yang dikatakan sebagai precise justice, maka ukuran-ukuran yang bersifat materiil, yang nyata-nyata dilandasi oleh asas-asas keadilan yang bersifat umum benar-benar harus diperhatikan dalam penegakan hukum.

Peran Polri dalam penanganan tindak pidana penipuan berupa pembayaran dengan memakai cek giro kosong merupakan tujuan dari penyelenggaraan sistem peradilan pidana seperti diamanatkan oleh Kitab UndangUndang Hukum Acara Pidana adalah untuk mencari kebenaran materiil (substantial truth) dan melindungi hakhak asasi manusia (protection of human rights). Tujuan ini merupakan tujuan besar dan utama dari proses sistem peradilan Pidana. penyelenggaraan kegiatan mencari kebenaran materiil meskipun bermuara di dalam pemeriksaan sidang Pengadilan, hendaknya proses kegiatan ini dimulai dari pemeriksaan di tingkat penyidikan oleh sub sistem kepolisian, sebab sub kepolisian ini merupakan pintu gerbang yang dapat menentukan suatu dugaan terjadinya tindak pidana itu dapat dipertanggungjawabkan atau tidaknya bagi pelaku yang diperiksa dapat di identifikasikan. Dengan demikian apa yang hendak dilakukan oleh setiap penegak hukum yang menurut fungsifungsinya harus dilaksanakan dalam proses sistem peradilan pidana tersebut, tidak boleh menjadi dominan. Fungsi penyidikan, penuntutan dan mengadili haruslah ditundukkan kepada tujuan besar dan utama yakni subtantial dan protection of human rights.

Peran Polri sebagai penyidik pada criminal justice system tindak pidana penipuan berupa pembayaran dengan memakai cek giro kosong pada hakikatnya merupakan fungsionalisasi hukum pidana (Arief, 1991: 2) artinya fungsionalisasi 
memegang peranan penting dalam suatu penegakan hukum, Barda Nawawi Arief menyatakan bahwa fungsionalisasi hukum pidana dapat berfungsi, beroperasi atau bekerja dan terwujud secara nyata. Fungsionalisasi hukum pidana identik dengan operasionalisasi atau konkretitasi hukum pidana, yang hakikatnya sama dengan penegakan hukum Fungsionalisasi hukum pidana dapat diartikan sebagai upaya untuk membuat hukum pidana dapat berfungsi, beroperasi atau bekerja dan terwujud secara nyata. Fungsionalisasi hukum pidana identik dengan operasionalisasi atau konkretisasi hukum pidana, yang hakikatnya sama dengan penegakan hukum. Dalam fungsionalisasi ini terdapat tiga tahapan kebijakan yaitu tahap kebijakan formulatif sebagai suatu tahap perumusan hukum pidana oleh pihak pembuat perundang-undangan. tahap kebijakan aplikatif sebagai tahap penerapan hukum pidana oleh penegak hukum, tahap kebijakan administratif, yaitu merupakan tahap pelaksanaan oleh aparat eksekusi hukum.

$\begin{array}{lrr}\text { Dengan demikian } & \text { sistem } \\ \text { peradilan pidana dalam rangka } & \text { ran } \\ \text { penyelenggaraannya } & \text { sebagaimana }\end{array}$
dimaksud oleh KUHAP harus merupakan kesatuan yang bergerak secara terpadu. dalam hal usaha-usaha untuk menanggulangi tindak pidana yang sesungguhnya terjdai dalam masyarakat. Sebagai suatu sistem, peradilan pidana mempunyai perangkat struktur atau subsistem yang seharusnya bekerja secara koheren, koordinatif dan integratif agar dapat mencapai efisiensi dan efektivitas yang maksimal. Sub-sub sistem ini berupa Polisi, Jaksa, Pengadilan dan Lembaga Koreksi baik yang sifatnya institusional maupun non konstitusional. Dalam hal ini mengingat peranannya yang semakin besar, penasehat hukum dapat dimasukkan sebagai quasi sub-sistem.

Cara profesionalisme menanggulangi tindak pidana adalah dengan cara menggabungkan pelaksanaan semua cabang dalam sistem peradilan pidana. Setiap lembaga yang terkait tetap melaksanakan tugas masing-masing, baik secara personil maupun dari hasil-hasil yang dicapai. Namun pada hakikatnya mereka melaksanakan semua kebijaksanaan kriminal untuk mencapai tujuan bersama. Dengan demikian keempat instansi penegak hukum, yaitu kepolisian, kejaksaan, pengadilan serta lembaga pemasyarakatan merupakan instansi yang administrasi struktural, masing-masing berdiri sendiri. Namun secara fungsional instansi-instansi tersebut terkait satu sama lain dan tidak terpisahkan atau terpadu.

Terpadu berarti terdapat suatu keterpaduan, sikap dan langkah terhadap pencegahan serta pemberantasan kejahatan menurut kepentingannya dan lembaganya sendiri. Masing-masing komponen dalam proses peradilan pidana tidak mungkin akan dapat menanggulangi pencegahan dan pemberantasan kejahatan menurut kepentingannya dan lembaganya sendiri.

Kombinasi antara efisiensi dan efektivitas dalam sistem sangat penting, sebab belum tentu efisiensi masingmasing sub-sistem, dengan sendirinya menghasilkan efektivitas. Kegagalan pada sub-sistem akan mengurangi efektivitas sistem tersebut, bahkan dapat menjadikan sistem tersebut disfungsional. Dengan demikian dapatlah dipikirkan betapa pentingnya koordinasi dalam sistem peradilan pidana. Koordinasi terjadi jika masing-masing badan penegak hukum dapat memahami arti pentingnya pekerjaan yang dilakukan bagi pencapaian tujuan bersama. Sistem peradilan pidana adalah sistem pengendalian kejahatan yang terdiri atas lembaga-lembaga Kepolisian, Kejaksaan, Pengadilan dan Pemasyarakatan terpidana. Lebih lanjut sistem ini dikatakan Mardjono sebagai bejana berhubungan.

Sistem peradilan pidana yang terdiri dari komponen Kepolisian, Kejaksaan, Pengadilan dan Lembaga Pemasyarakatan merupakan suatu proses yang diharapkan masyarakat untuk dapat gerak terpadu dalam mencapai suatu hukum yang 
dikehandaki bersama yaitu mencegah terjadinya kejahatan. Untuk mencapai suatu sitem peradilan pidana terpadu diperlukan perbaikan atau pembaharuan (reformasi) perangkat hukumnya, yaitu hukum pidana itu sendiri, baik menyangkut hukum formal (acara) meupun hukum pidana materiil (aturanaturan yang ada di dalam maupun di luar KUHP). Sistem peradilan pidana oleh karenanya merupakan sistem yang berbeda bila dibandingkan dengan sebagian besar sistem sosial lain karena menimbulkan keadaan yang tidak sejahtera bagi yang dikenal". Hulsman mengkiaskan sistem peradilan pidana sebagai kotak hitam (black box)".

Sebelum dikeluarkannya UndangUndang Republik Indonesia Nomor 8 Tahun 1981 tentang Hukum Acara Pidana, sistem peradilan pidana di Indonesia dilandaskan pada Het Herziene Reglement (HIR) Staatblad (STBL) 1941 Nomor 44. Dengan berlakunya Undang-Undang Hukum Acara Pidana telah menimbulkan perubahan fundamental baik secara konsepsional maupun implementasi terhadap tata cara penyelesaian perkara pidana di Indonesia.

Perubahan sistem peradilan yang dianut melaui Undang-Undang tersebut diatas mengakibatkan adanya perubahan dalam cara berfikir, cara bertindak para aparat pelaksana penegak hukum secara keseluruhan. Dilihat dari segi ilmu pengetahuan hukum acara pidana, perubahan cara berfikir ini sangat penting artinya dalam keterkaitannya terhadap cara bersikap dan bertindak khususnya bagi aparat penegak hukum pidana. Suatu Undang-Undang yang secara konseptual baik, namun dalam kontekstual terkadang bukan hanya tidak efektif tetapi sekaligus menjadi tidak memiliki nilai-nilai (values) yang dianggap baik dan adil, apabila tidak didukung oleh penghayatan yang baik atas nilai yang terkandung pada konsep Undang-Undang yang dimaksud.

Sistem peradilan pidana dapat digambarkan secara singkat sebagai suatu sistem yang bertujuan untuk menanggulangi kejahatan, salah satu usaha masyarakat untuk mengendalikan terjadinya kejahatan agar berada dalam batas-batas toleransi yang dapat diterimanya. Dengan demikian seluruh rangkaian bekerjanya sub-sub sistem peradilan pidana dari mulai in-put sampai out-put nya hendaknya memiliki pemahaman-pemahaman yang sama dalam kerangka menanggulangi kejahatan.

Jika ditelaah secara teliti isi ketentuan sebagaimana dimuat dalam Undang-Undang Nomor 8 Tahun 1981 tentang Hukum Acara Pidana, maka sistem peradilan pidana Indonesia yang terdiri dari komponen Kepolisian, Kejaksanaan, Pengadilan dan Lembaga Pemasyarakatan sebagai aparat penegak hukum, setiap komponen dari sistem tersebut seharusnya secara konsisten menjaga agar sistem tetap berjalan secara terpadu.

Keempat aparat tersebut mempunyai hubungan yang sangat erat satu sama lain bahkan, sebagai konsekuensinya bila salah satu sub sistem mengalami kegagalan dalam bertindak maka berakibat kegagalan bagi sub sistem lainnya dalam usaha menanggulangi kejahatan. Pelaksanaan penegakan hukum berdasarkan UU No. 8 Tahun 1981 tentang Hukum Acara Pidana secara imperatif merupakan suatu usaha yang sistematis dan saling melakukan keterpaduan. Terpadu yang dimaksud dalam penegakan hukum pidana ini merupakan penegasan sistem peradilan pidana yang berarti terdapat suatu keterpaduan pendapat, sikap dan langkah terhadap pencegahan serta pemberantasan kejahatan dalam suatu masyarakat.

Masing-masing komponen dalam proses peradilan pidana tidak mungkin dapat melakukan pemberantasan terhadap kejahatan yang terjadi kalau saja hanya mengutamakan kepentingan bagi lembaganya sendiri-sendiri tanpa melakukan koordinasi dan melihat kepentingan terbesar dari suatu sistem. Masing-masing komponen merupakan 
sub-sistem dalam keseluruhan sistem peradilan pidana.

Dalam sistem peradilan pidana terpadu, bekerjanya sub-sistem harus terintegrasi (terpadu) dengan sub sistem lainnya, harus ada persamaan persepsi dalam memahami persoalan hukum pidana yang terjadi dengan tetap melihat tujuan pokok adanya sistem peradilan pidana. Oleh karena itu apabila sejak awal telah terjadi ketidakterpaduan sudah dapat dipastikan bekerjanya sistem sebagai sarana hukum pidana dapat mengalami kegagalan yang pada gilirannya maka kepercayaan masyarakat terhadap subsistem tersebut secara keseluruhan akan hilang. Bahkan lebih ekstrim lagi, masyarakat tidak lagi mempercayai subsistem secara institutif dalam arti sempit dan sistem peradilan pidana dalam arti yang lebih luas.

Suatu sistem peradilan pidana di dalam penanganan tindak pidana penipuan berupa pembayaran dengan memakai cek giro kosong yang baik harus menyadari keterbatasannya dalam menyampaikan kepada masyarakat bahwa tugas mereka memang adalah hanya menjaga ketertiban umum (public order maintenance) di dalam pengertian ketertiban umum di sini dimaksudkan pula melindungi masyarakat terhadap tindak pidana-tindak pidana yang secara nyata telah merugikan dan meresahkan masyarakat.

Keterlibatan berbagai badan penegak hukum dengan fungsi yang berbeda-beda tetapi dengan tujuan yang sama memerlukan persepsi sistem, artinya lembaga sub sistem Kepolisian, sub sistem Penuntutan, sub sistem Pengadilan, sub sistem Lembaga Pemasyarakatan yang melaksanakan proses tersebut hendaknya dilihat sebagai suatu sistem yaitu sistem penyelenggaraan peradilan pidana (criminal justice system).

Masalah pokok daripada penegakan hukum pada umumnya dan penegakan hukum tindak pidana penipuan berupa pembayaran dengan memakai cek giro kosong serta untuk mengukur profesionalisme penegakan hukum sebenarnya terletak pada faktor-faktor yang mempengaruhinya. Faktor-faktor tersebut mempunyai arti yang netral, sehingga dampak positif atau negatifnya terletak pada isi faktor-faktor tersebut.

Adapun faktor-faktor yang mempengaruhi penegakan hukum dikatakan Soerjono Soekanto terdiri dari: 1) Faktor hukumnya sendiri yang dalam hal ini dibatasi pada Undang-Undang saja; 2) Faktor penegakan hukum, yakni pihakpihak yang membentuk maupun menerapkan hukum; 3) Faktor sarana atau fasilitas yang mendukung penegakan hukum; 4) Faktor masyarakat, yakni lingkungan di mana hukum tersebut berlaku atau diterapkan, 5) Faktor kebudayaan, yakni sebagai hasil karya, cipta dan rasa yang didasarkan pada karsa manusia di dalam pergaulan masyarakat. (Arief, 1991: 2)

Kelima faktor tersebut di atas saling berkaitan dengan eratnya, oleh karena merupakan esensi dari penegakan hukum, serta juga merupakan tolok ukur daripada efektivitas penegakan hukum yang terpadu. Hubungan kerja sama tersebut di atas akan dapat mendekatkan pendirian masing-masing instansi penegak hukum dan akan memberikan citra positif untuk semua pihak khususnya sinkronisasi antara sub-sub sistem yang satu terhadap sub sistem peradilan pidana lainnya, sebab keberhasilan satu pihak dalam penyelenggaraan peradilan pidana mempunyai arti keberhasilan semua pihak. Pertanggungjawaban pidana penipuan pembayaran melalui cek kosong adalah membicarakan tentang dapat atau tidaknya pelaku yang melakukan pembayaran dengan cek kosong tersebut dipidana atas perbuatannya tersebut. Apabila perbuatan penipuan pembayaran melalui cek kosong tersebut dilakukan secara sengaja, selanjutnya dilakukan secara sadar oleh seseorang yang waras serta diketahui perbuatan penipuan pembayaran melalui cek kosong tersebut ada diatur di dalam perundang-undangan yaitu Pasal 378 KUHP, maka pada 
kapasitas ini pelaku penipuan pembayaran melalui cek kosong dapat dimintakan pertanggungjawaban hukumnya.

Berdasarkan hal tersebut maka untuk dapat dimintakan pertanggungjawaban pidana seorang pelaku penipuan pembayaran melalui cek kosong maka harus dipenuhi hal-hal adalah adanya unsur kesengajaan (dolus) atau kelalaian (culpa). Adanya unsur kesengajaan atau kelalaian merupakan salah satu syarat untuk dapat dipertanggungjawabnya pembuat delik. Perlu diingat bahwa sebagaian besar penulis hukum pidana mengatakan bahwa sengaja itu suatu pengertian yang tidak berwarna, artinya tidak perlu pembuat mengetahui bahwa perbuatannya itu dilarang oleh undang-undang. Mengenai kelalaian undang-undang tidak memberi defenisi apakah kelalaian itu, hanya memori penjelasan (memorie van Teolichting) mengatakan, bahwa kelalaian (culpa) terletak antara sengaja dan kebetulan. Bagaimana pun juga culpa itu dipandang lebih ringan dibanding dengan sengaja.

Apabila dilihat ketentuan pidana Pasal 378 KUH Pidana sebagai dasar hukum pengaturan perbuatan penipuan pembayaran melalui cek kosong maka dapat dilihat bahwa penipuan tersebut dilakukan secara sengaja. Supaya masuk pasal ini, maka penipuan pembayaran melalui cek kosong tersebut harus dibuktikan ada orang dengan melawan hak melakukan penipuan, tidak melakukan sesuatu atau membiarkan sesuatu tersebut terjadi.

Apabila uraian tersebut dilihat maka jelas dapat dipahami perbuatan pelaku penipuan pembayaran melalui cek kosong adalah suatu perbuatan yang sengaja (dolus). Kesengajaan tersebut tentunya mempunyai maksud agar orang lain tidak mengetahui perbuatannya. Suatu hal yang pantas menjadi perhatian adalah kesengajaan tersebut berupa tindakan penipuan pembayaran melalui cek kosong. Pada Putusan Pengadilan Negeri Medan No. 1123/Pid.B/2014/PN.MDN terlihat sengaja tersebut menggerakkan orang lain untuk menyerahkan barang sesuatu kepadanya atau supaya member hutang maupun menghapus piutang.

Uraian di atas menjelaskan bahwa perbuatan pelaku penipuan pembayaran melalui cek kosong adalah perbuatan yang sengaja dilakukan sehingga terjadinya hajat yang diinginkan yaitu keuntungan. Untuk kesengajaan kemudian dibagi kembali menjadi, yaitu: a. Sengaja sebagai maksud (opzet als oogmark); b. Sengaja dengan kesadaran tentang kepastian (opzet met bewustheid van zekerheid of noodzakelijkheid); c. Sengaja dengan kesadaran kemungkinan sekali terjadi (opzet met waarschijnlijkheidsbewustijn).

Apabila kesengajaan tersebut sebagaimana diterangkan di atas dihubungkan dengan tindak pidana sebagaimana diatur dalam Pasal $378 \mathrm{KUH}$ Pidana, maka dapat dilihat tindak pidana penipuan pembayaran melalui cek kosong adalah sengaja sebagai maksud. Artinya dengan perbuatannya tersebut pelaku tindak pidana penipuan pembayaran melalui cek kosong mengetahui akibat perbuatannya tersebut dapat dikenakan pertanggungjawaban pidana.

Berdasarkan hal tersebut yang ditemukan dalam ketentuan Pasal 378 KUHP ini adalah kesengajaan. Menurut Moeljatno "pidana hendaknya dijatuhkan hanya pada barang siapa melakukan perbuatan yang dilarang dengan dikehendaki dan diketahui". Apakah yang dimaksud dengan dikehendaki dan diketahui (willens en werens). Mengenai hal ini ada 2 teori yaitu: a) Teori kehendak (willstheorie), yang menitikberatkan pada segi kehendak (willens) atau apa yang dikehendaki; dan b) Teori pengetahuan (voorstellings theorie), yang menitikberatkan pada segi pengetahuan atau apa yang dibayangkan.

Menurut teori kehendak, kesengajaan itu adalah kehendak yang diarahkan untuk mewujudkan perbuatan dan unsur-unsur lain yang dirumuskan dalam tindak pidana. Sedangkan menurut 
teori pengetahuan, kesengajaan adalah apa yang diketahui atau dapat dibayangkan petindak sebelum ia mewujudkan perbuatan sebagaimana yang dirumuskan dalam tindak pidana.

Seorang dapat dikenakan ketentuan Pasal 378 KUHP yaitu melakukan tindak pidana penipuan pembayaran melalui cek kosong, tidak dimungkinkan terbebas dari kesengajaan yang dilahirkan dari teori kehendak. Artinya si pelaku memang berkehendak melakukan penipuan tersebut. Perbuatan pelaku tersebut juga sangat melekat apabila kesengajaan sebagaimana yang dianut oleh Pasal 378 KUHP dikaitkan dengan dengan teori pengetahuan. Pada kapasitas ini seorang mengetahui apabila ia melakukan tindak pidana penipuan pembayaran melalui cek kosong ia dapat dipidana, maka dalam kapasitas ini ketentuan Pasal 378 KUHP dapat dikenakan kepada kepada seseorang yang melakukan tindak pidana penipuan pembayaran melalui cek kosong.

Hal ini dapat dipastikan karena telah terpenuhinya unsur kesengajaan dari perilaku seseorang yang melakukan tindak pidana penipuan pembayaran melalui cek kosong. Terpenuhinya unsur kesengajaan tersebut adalah dari teori pengetahuan sebagaimana diuraikan di atas. Kesengajaan sebagai maksud atau tujuan (opzet als oogmerk) atau disebut dolus directur, adalah jenis kesengajaan yang paling sederhana. Jenis kesengajaan ini lebih mudah dilakukan pembuktian dengan melihat kenyataan-kenyataan yang menghubungkan antara si pelaku dengan tindak pidana yang dilakukan.

Ada perbedaan antara dua teori tersebut namun sesungguhnya perbedaan itu hanya berbeda pokok pangkal atau titik berat pandangan belaka, pada kenyataannya tidak ada perbedaan, dalam arti menghasilkan kesimpulan yang sama. Karena orang berbuat untuk mencapai apa yang ia kehendaki, adalah berarti ia berbuat terhadap apa yang ia telah diketahui. Atau dengan kata lain seorang yang melakukan tindak pidana penipuan pembayaran melalui cek kosong tentunya

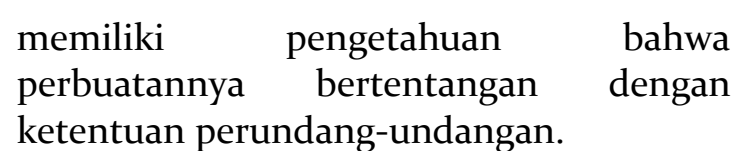

Hal yang ditemukan dalam praktek penerapan peraturan perundangundangan di Indonesia, khususnya dalam kaitan antara penerapan ketentuan Pasal 378 KUHP dengan peristiwa seseorang yang melakukan tindak pidana penipuan pembayaran melalui cek kosong adalah dikenalnya sifat kesengajaan tersebut.

Menurut sifatnya ada dua jenis kesengajaan, pertama, adalah Dolus malus, yaitu dalam hal seseorang melakukan tindak pidana, tidak saja ia hanya menghendaki tindakannya itu, tetapi juga ia menyinsyafi bahwa tindakannya itu dilarang oleh undang-undang dan diancam dengan pidana. Kedua adalah kesengajaan yang tidak mempunyai sifat tertentu (kleurloos begrif), yaitu dalam hal seseorang melakukan suatu tindak pidana tertentu, cukuplah jika (hanya) menghendaki tindakannya itu. Artinya ada hubungan yang erat antara kejiwaan (bathin) dengan tindakannya. Tidak disyaratkan apakah ia menginsyafi bahwa tindakannya itu dilarang dan diancam dengan pidana oleh undang-undang.

Ajaran yang pertama sudah tidak dianut lagi, karena apabila ajaran itu tetap dipertahankan, akan memberikan beban yang sangat berat bagi para penegak hukum, terutama hakim. Menurut teori ini, hakim wajib untuk membuktikan bahwa pelaku (terdakwa) betul-betul menginsyafi bahwa tindakannya itu dilarang dan diancam dengan pidana oleh undang-undang. Padahal untuk membuktikan kehendak saja sudah sulit. Akan semakin sulit jika keinsyafan tersebut harus dibuktikan. Seperti diketahui tidak semua orang yang pernah membaca atau mendengar tentang tindakan mana yang dilarang dan diancam dengan pidana oleh undang-undang. Maka wajar jika kemudian yang dianut adalah ajaran yang kedua, yang di samping lebih sederhana sudah memenuhi kebutuhan.

Kesengajaan jenis kedua inilah yang dianut dalam hukum pidana Indonesia. 
Hukum pidana menentukan untuk dapat dipidananya seseorang (pelaku) tidak tergantung dari keinsyafan, apakah suatu tindakan dilarang dan diancam dengan pidana. Sebagai imbalannya ialah bahwa hanya tindakan tertentu (yang harus diatur dalam undang-undang) yang ditentukan sebagai kejahatan, yang oleh setiap orang yang berpendidikan normal dapat mengetahui bahwa tindakan tersebut bertentangan dengan ketertiban masyarakat.

Kapasitas ini maka dapat dilihat bahwa orang yang berpendidikan normal dapat menyangka meskipun ia tidak membaca undang-undang bahwa perbuatan seseorang yang melakukan pengancaman akan menghilangkan jiwa orang lain adalah melawan hukum. Tetapi seorang yang melakukan tindak pidana penipuan pembayaran melalui cek kosong, maka dalam kapasitas ini ketentuan Pasal 378 KUHP dapat dikenakan kepada pelaku.

Uraian di atas sama tepatnya dengan apa yang dikemukakan oleh Moelyatno, sedianya terdakwa ingin menembak babi hutan, tetapi karena di waktu menembak, dia mengerti bahwa di sekitar babi ada banyak orang desa yang menguber-uber binatang tersebut, dan akibatnya yang kena tembakan bukan saja babi, tetapi juga salah seorang di antara penguber tadi (atau babi tidak kena sama sekali) maka matinya orang itu dikatakan disengaja pula. Kalau dia insyaf akan kepastian tertembaknya orang tadi kesengajaan terhadap akibat itu dinamakan kesengajaan sebagai kepastian, dan kalau yang diinsyafi hanya kemungkinannya saja, kesengajaan sebagai kemungkinan. Akibatnya terdakwa melanggar Pasal 338 KUHP. (Moeljatno, :192-193)

Berdasarkan uraian di atas maka jelaslah bahwa perbuatan seseorang yang melakukan tindak pidana penipuan pembayaran melalui cek kosong sebagaimana diatur dalam Pasal $378 \mathrm{KUH}$ Pidana adalah merupakan kesengajaan dan bukan merupakan kelalaian (culpa).
Untuk kelalaian, Van Hamel membagi culpa atas dua jenis, yaitu pertama, kurang melihat kedepan yang perlu (jika terdakwa tidak membayangkan secara tepat atau sama sekali tidak membayangkan akibat yang akan terjadi). Kedua, kurang hati-hati yang perlu (misalnya ia menarik picu pistol karena mengira tidak ada isinya).

Undang-undang termasuk $\mathrm{KUH}$ Pidana tidak ada menjelaskan pengertian atau definisi tentang kelalaian itu. Hanya memori penjelasan (memorie van toelichting) mengatakan bahwa kelalaian (culpa) terletak antara sengaja dan kebetulan. Bagaimanapun juga culpa itu dipandang lebih ringan dibanding dengan sengaja. Oleh karena itu Hazewinkel Suringa mengatakan bahwa delik culpa itu merupakan delik semu (quasidelict) sehingga diadakan pengurangan pidana. Bahwa culpa itu terletak antara sengaja dan kebetulan kata Hazewinkel Suringa dikenal pula di negara-negara Anglo Saxon yang disebut per infortuninum the klling occurred accidently. Dalam memori Jawaban Pemerintah (MvA) mengatakan bahwa siapa yang melakukan kejahatan dengan sengaja berarti mempergunakan salah kemampuannya sedangkan siapa karena salahnya (culpa) melakukan kejahatan berarti tidak mempergunakan kemampuannya yang ia harus mempergunakan (Hamzah, 1995: 125).

Kealpaan memiliki sifat-sifat atau ciri-cirinya yaitu:

Sengaja melakukan suatu tindakan yang ternyata salah, karena menggunakan ingatan/otaknya secara salah, seharusnya ia menggunakan ingatannya (Sebaikbaiknya), tetapi ia tidak digunakan. Dengan perkataan lain ia telah melakukan suatu tindakan (aktif atau pasif) dengan kurang kewaspadaan yang diperlukan. Pelaku dapat memperkirakan akibat yang akan terjadi, tetapi merasa dapat mencegahnya. Sekiranya akibat itu pasti akan terjadi, dia lebih suka untuk tidak melakukan tindakan yang akan menimbulkan akibat itu. Tetapi tindakan itu tidak diurungkan, atas tindakan mana 
ia kemudian dicela, karena bersifat melawan hukum. (EY Kanter dan SR Sianturi, 2003: 192)

Memorie van toelichting menjelaskan bahwa dalam hal kealpaan, pada diri pelaku terdapat: a) Kekurang pemikiran (penggunaan akal) yang diperlukan, b) Kekurang pengetahuan (ilmu) yang diperlukan) dan c) Kekurangan kebijaksanaan (beleid) yang diperlukan. (Hamzah, 1995: 125)

Unsur kealpaan, seperti juga kesengajaan adalah salah satu bentuk dari kesalahan. Kealpaan adalah bentuk yang lebih rendah derajatnya daripada kesengajaan. Tetapi dapat pula dikatakan bahwa kealpaan itu adalah kebalikan dari kesengajaan, karena bila mana dalam kesengajaan, sesuatu akibat yang timbul itu dikehendaki pelaku, maka dalam kealpaan, justri akibat itu tidak dikehendaki, walaupun pelaku dapat memperkirakan sebelumnya. Disinilah juga letak salah satu kesukaran untuk membedakan antara kesengajaan bersyarat dengan kealpaan berat.

Kealpaan mengandung dua syarat, yaitu Tidak mengadakan penduga-duga sebagaimana diharuskan oleh hukum dan tidak mengadakan penghati-hati sebagaimana diharuskan oleh hukum (Syarifin, 2000: 89). Berdasarkan ketentuan tersebut, dapat diikuti dua jalan, yaitu yang pertama memperhatikan syarat tidak mengadakan penduga-duga menurut semestinya. Yang kedua memperhatikan syarat tidak mengadakan penghatti-hati guna menentukan adanya kealpaan. Siapa saja yang melakukan perbuatan tidak mengadakan penghatihati yang semestinya, ia juga tidak mengadakan penduga-duga akan terjadinya akibat dari kelakuannya.

Ada kealpaan yang disadari dan kealpaan yang tidak disadari. Dengan demikian tidak mengadakan pendugaduga yang perlu menurut hukum terdiri atas dua kemungkinan, yaitu: Terdakwa tidak mempunyai pikiran bahwa akibat yang dilarang mungkin timbul karena perbuatannya dan Terdakwa berpikir bahwa akibat tidak akan terjadi ternyata tidak benar (Syarifin, 2000: 89).

Unsur lainnya dapat dimintakan pertanggungjawaban pidana kepada seorang yang melakukan tindak pidana penipuan pembayaran melalui cek kosong adalah tidak adanya alasan peniadaan pidana dalam perbuatan seorang tersebut. Tidak adanya alasan peniadaan pidana merupakan syarat untuk dapat dipertanggungjawabkannya pembuat delik. jika terdapat alasan terhadap peniadaan pidana maka pembuat delik tidak dapat dipertanggungjawabkan atas perbuatannya. Adapun yang merupakan alasan peniadaan pidana, yaitu sebagai berikut: a) Keadaan darurat (Pasal 48 KUHP), b) Pembelaan terpaksa (Pasal 49 ayat 1 KUHP), c) Menjalankan peraturan perundang-undangan (Pasal 5o KUHP), d) Menjalankan perintah jabatan yang sah (Pasal 51 ayat 1 KUHP), e) Tidak mampu bertanggungjawab (Pasal 44 KUHP), f) Daya paksa (Pasal 48 KUHP), g)Pembelaan terpaksa melampaui batas (Pasal 49 ayat 2 KUHP), h) Menjalankan perintah jabatan yang sah (Pasal 51 ayat 2 KUHP).

Berdasarkan uraian di atas apabila dilihat perbuatan seorang yang melakukan tindak pidana penipuan pembayaran melalui cek kosong bukan disebabkan adanya alasan peniadaan pidana tetapi dilakukan secara segaja. Sebagaimana diketahui, alasan peniadaan pidana tersebut ada yang berupa alasan pembenar dan juga berupa alasan pemaaf. untuk huruf a sampai dengan $d$ tersebut merupakan alasan pembenar. Dan untuk huruf e sampai dengan huruf $h$ adalah merupakan alasan pemaaf.

Melawan hukum juga merupakan suatu unsur dapat dimintakannya pertanggungjawaban pidana seorang yang melakukan tindak pidana penipuan pembayaran melalui cek kosong sebagaimana diatur dalam Pasal $378 \mathrm{KUH}$ Pidana.

Melawan hukum itu sendiri banyak pengertiannya, melawan hukum bisa juga diartikan sebagai tanpa hak sendiri (zonder eigen recht), ada juga yang 
mengartikan bertentangan dengan hak orang lain (tegen eens anders recht), dan juga ada yang mengartikan dengan, bertentangan dengan hukum objektif (tegen het objectieve recht). Dan yang jelas, melawan hukum merupakan bagian inti (bestanddeel) delik, artinya adalah secara jelas dirumuskan dalam rumusan delik. Dalam perjalannya melawan hukum dapat dibagi ke dalam: a) Melawan hukum formil yaitu perbuatan yang bertentangan dengan undang-undang. b) melawan hukum Materiil yaitu perbuatan perbuatan yang tercela dan bertentangan dengan rasa keadilan masyarakat.

Melawan hukum materil dibagi kembali ke dalam: a). Melawan hukum dalam fungsi negatif yaitu meski perbuatan memenuhi unsur tindak pidana tetapi tidak bertentangan dengan rasa keadilan masyarakat, maka perbuatan itu tidak dipidana. b). Melawan hukum dalam fungsi positif yaitu meski perbuatan tidak memenuhi unsur tindak pidana, tetapi jika perbuatan itu dianggap tercela karena tidak sesuai rasa keadilan atau norma dalam masyarakat, maka perbuatan itu dapat dipidana.

Hakim sebagai orang yang menjalankan hukum berdasarkan demi keadilan di dalam menjatuhkan putusan terhadap perkara yang ditanganinya tetap berlandaskan aturan yang berlaku dalam undang-undang dan memakai pertimbangan berdasarkan data-data uang autentik serta para saksi yang dapat dipercaya. Tugas hakim tersebut dalam mempertimbangkan untuk menjatuhkan suatu putusan bebas dapat dilihat dalam Pasal 191 ayat (1) KUHAP yang menyatakan: "jika pengadilan bar pendapat bahwa dari hasil pemeriksaan di sidang, kesalahan terdakwa atas perbuatan yang didakwakan kepadanya tidak terbukti secara sah dan menyakinkan, maka terdakwa diputus bebas.

Berdasarkan uraian di atas maka dapat dipahami bahwa pertimbangan hukum hakim dalam menjatuhkan putusannya adalah: 1) Jenis dari perbuatan pidana yang didakwakan kepada terdakwa;
2) Terbuktinya dakwaan yang didakwakan kepada terdakwa; 3) Terpenuhinya unsurunsur perbuatan pidana terdakwa; 4) Halhal yang memberatkan; 5) Hal-hal yang meringankan; 6) Tidak adanya unsur menghilangkan tanggungjawab Terdakwa.

\section{SIMPULAN}

Pengaturan hukum terhadap tindak pidana pembayaran melalui cek giro kosong diatur dalam Pasal $378 \mathrm{KUH}$ Pidana. Artinya tindak pidana pembayaran melalui cek giro kosong tersebut dimasukkan ke dalam klasifikasi tindak pidana penipuan sebagaimana diatur dalam Pasal 378 KUH Pidana. Pihak yang terlibat dalam penanganan tindak pidana pembayaran melalui cek giro kosong adalah kepolisian. Karena Fungsi kepolisian adalah salah satu fungsi pemerinatahan negara di bidang pemeliharaan keamanan dan ketertiban masyarakat, penegakan hukum, perlindungan, penganyoman, dan pelayanan kepada masyarakat. Pertanggungjawaban hukum bagi pelaku tindak pidana pembayaran melalui cek giro kosong tersebut dipidana atas perbuatannya tersebut. Apabila perbuatan pengancaman tersebut dilakukan secara sengaja, selanjutnya dilakukan secara sadar oleh seseorang yang waras serta diketahui perbuatan penipuan tersebut ada diatur di dalam perundang-undangan yaitu Pasal 378 KUHP, maka pada kapasitas ini pelaku penipuan dapat dimintakan pertanggungjawaban hukumnya.

\section{DAFTAR PUSTAKA}

Arief, B.N., (1991), Kebijakan Kriminal, Makalah disampaikan pada Seminar Krimonologi VI, Semarang, Tanggal 16-18 September 1991.

Arifin, S., (2012), Metode Penulisan Karya Ilmiah dan Penelitian Hukum, Medan: Medan Area University Press.

Atmasasmita, R., (1989), Asas-Asas Perbandingan Hukum Pidana, Jakarta: Yayasan LBH Indonesia. 
Bassar, M.S., (1986), Tindak-Tindak Pidana Tertentu Dalam KUHP, Bandung: Remaja Karya.

Chazawi, A., (2001), Pelajaran Hukum Pidana I Bagian I, Raja Grafindo Persada, Jakarta.

Chazawi, A., (2003), Kejahatan Terhadap Harta Benda, Bayu Media, Malang.

Departemen Pendidikan Nasional, Kamus Besar Bahasa Indonesia, Gramedia Pustaka Utama, Jakarta, 2008.

Dirdjosisworo, S., (1998), Polisi Dalam Sistem Peradilan Pidana Indonesia, Majalah Bhayangkara No. 05, Juli 1998.

Effendi, E, (2011), Hukum Pidana Indonesia, Suatu Pengantar, Refika Aditama, Jakarta, 2011.

Gunadi, I., (2011), Cepat dan Mudah Memahami Hukum Pidana, Jakarta: Prestasi Pustaka.

Hadikusuma, H. (1992), Bahasa Hukum Indonesia, Bandung: Alumni.

Hamzah, A., (1983), Pengantar Hukum Acara Pidana Indonesia, Ghalia Indonesia, Jakarta.

Kadir, M.A., (2003), Hukum Dagang Tentang Surat Berharga, Bandung: Mandar Madju.

Kancil, CST., dkk., (2009), Tindak Pidana Dalam Undang-Undang Nasional, Jala Permata Aksara, Jakarta.

Kanter, EY., dan SR Sianturi, (2003), Asas-Asas Hukum Pidana di Indonesia, Storia Grafika, Jakarta.

Kompasiana, "Pengertian Tindak Pidana", http://hukum.kompasiana.com/2011/ 10/ 18/pengertian-tindak-pidana/.

Lamintang, PAF., (1997), Dasar-Dasar Hukum Pidana Indonesia, Bandung: Citra Aditya.

Loqman, L., (1987), Praperadilan Indonesia, Jakarta: Ghalia Indonesia.

Moeljatno, (2002), Asas-Asas Hukum Pidana, Jakarta: Rineka Cipta.

Mubarak, R, (2016), Disparitas Pemidanaan Pelaku Tindak Pidana Kekerasan pada Perempuan, Jurnal Pendidikan Ilmu-Ilmu Sosial, 8 (1) (2016): 34-47
Muladi, (1995), Kapita Selekta Sistem Peradilan Pidana, Semarang: UNDIP.

Nasution, B.J., (2008). Metode Penelitian Ilmu Hukum. Mandar Maju, Bandung.

Priyatno, D., (2004), Kebijakan Legislatif Tentang Sistem Pertanggungjawaban Pidana Korporasi di Indonesia, Utomo, Bandung.

Sabuan, A., Syafruddin P. dan Ruben A, (1990), Hukum Acara Pidana, Angkasa, Bandung.

Saleh, R., (1987), Sifat Melawan Hukum Dari Perbuatan Pidana, Jakarta: Aksara Baru.

Sidik Sunaryo, (2004), Kapita Selekta Sistem Peradilan Pidana, Malanag: UMM Pres.

Soesilo, R., (1991), Kitab Undang-Undang Hukum Pidana (KUHP) Serta KomentarKomentarnya Lengkap Pasal Demi Pasal, Bogor: Politeia.

Suryohadibroto, I.P., dan Djoko P, (2009), Surat Berharga Alat Pembayaran Masyarakat Modern, Jakarta: Bina Aksara.

Syarifin, P., (200o), Hukum Pidana di Indonesia, Bandung: Pustaka Setia.

Zebua, F.R.P., Iman J., dan Taufik S., (2008), Tanggungjawab Pelaku Tindak Pidana Korupsi dan Ahli Warisnya Dalam Pembayaran Uang Pengganti Kerugian Keuangan Negara Ditinjau Dari Aspek Hukum Perdata (Studi Kasus Pada Pengadilan Negeri Medan), Mercatoria, 1 (2): $150-162$

Kitab Undang-Undang Hukum Pidana

Undang-Undang No. 8 Tahun 1981 tentang Hukum Acara Pidana

Surat Edaran Bank Indonesia No. 2/10/DASP tanggal 8 Juni 2000 tentang Tata Usaha Penarikan Cek/Bilyet Giro Kosong

UG Community, "Penipuan dan Pengamanan Komputer".

http://community.gunadarma .ac.id/forums/display_topic/id_37255/PE NIPUAN-DAN-PENGAMANANKOMPUTER/ /. 